\title{
Vegetation Recovery of Logged-over Dipterocarp Forests In Central Kalimantan, Indonesia
}

\author{
Prijanto Pamoengkas ${ }^{1}$ (D), Ayi Zamzam¹ (D), Aji Dwisutono ${ }^{1}$ \\ ${ }^{1}$ Department of Silviculture, Faculty of Forestry, Bogor Agricultural University - IPB, Bogor/West Java, Indonesia
}

\begin{abstract}
Forest utilization usually has an impact on changes in forest structure and species composition. The species of trees selected and ecosystem management system that refer to biodiversity characteristics will be explained by better knowledge of Functional Species Group (FSG). The purpose of this study was to determine the composition of vegetation recovery based on FSG in production forest managed with silvicultural system known as Selective Cutting and Line Planting System (SCLP) and undisturbed forest known as Germplasm Preservation Areas (GPCA) in Central Kalimantan, Indonesia. The results showed that the proportion of climax group in the entire observation plots was greater than pioneer species group, i.e. climax 100 species and pioneer 59 species. Stand structure both climax and pioneer species group has inverse J shape curve. It means that the species composition of logged-over forest is still in balance condition, characterized with high index of diversity $\left(\mathrm{H}^{\prime}>3\right)$.
\end{abstract}

Keywords: functional species group, selective cutting, species composition, stand structure, biodiversity. 


\section{INTRODUCTION}

Undisturbed lowland dipterocarp forests have clean forest floor, various niches, high diversity; nutrients were saved in biomass (Ewusie, 1980; MacKinnon et al., 1996). Indonesia tropical rainforest is managed using single selective cutting. Some of the forest concessions implemented an intensive forest management system. The main activity of this system is selective cutting with minimum diameter limit and planting intensively in line to enrich standing stock. However, the selective cutting system is risky as it obviously affects the various species of a plant community unevenly. Any disturbances, such as logging or landslides result in stand or seedling damages, including changes in forest structure and composition (Hendrison, 1990; Cannon et al., 1994; Okuda et al., 2003), and in soil nutrients (Nussbaum et al., 1995). The effects of selective logging on structure and species composition and its implication to the second cutting cycle have been sparsely documented up to now. Information about the conditions of residual stands is important and urgently required. Such information is a basic prerequisite for estimating the harvestable volume for the next cutting cycle, and for scheduling timber stand improvement. Relatively comprehensive data exist for Kalimantan forests (Cannon et al., 1994). More importantly, it changes in ecological balance with changes in stand structure and species composition. One can explain the changes through study approach known as functional species group.

Functional Species Group (FSG) is a group of species having identical patterns of resource use, growth rate, death and regeneration (Gitay \& Noble, 1997). Better knowledge of FSG will explain the unity of the species of trees selected in a group on the harvesting, selection silvicultural techniques and ecosystem management system to explain its biodiversity characteristics such as its habitat quality and ecosystem processes (Pohris, 2009). Identification of functional groups can help understand and predict how communities and ecosystem properties might be affected by environmental changes.

Silvicultural system of Selective Cutting and Line Planting system (SCLP) is one of the systems for forest management to improve forest productivity through planting in line system. The SCLP was introduced and applied in logged-over forest (LoA). Suparna \& Purnomo (2004) stated that the objectives of utilizing dipterocarps species using SCLP is for managing natural forests to increase the productivity of tropical rainforest and maintain the biodiversity. The species of dipterocarps suitable on degraded forest would be recommended for rehabilitation program to conserve and increase the productivity of tropical rainforest.

Up to now the evaluation of silvicultural system SCLP is in progress. Evaluation is necessary as its application has not yet been tested until it reaches its 25 years cycle. One of the aspects to be evaluated is the ecological process (vegetation processes) in the intermediate line or conservation line. It consists of residual stand as wide as 17 meters, which is expected to maintain the biodiversity of the forest.

The objective of this study is to determine the stand structure and species composition of the logged-over forests based on FSG. The logged-over forests applied by Selective Cutting and Line Planting Silvicultural System (SCLP) with intensive silviculture technique.

\section{MATERIAL AND METHODS}

\subsection{Study site and time schedule}

The study was carried out in April-May 2014 in the production forest on logged-over forest areas in Central Kalimantan, Indonesia. Selective Cutting and Line Planting Silvicultural System (SCLP) with intensive silviculture technique have been applied in the logged-over forest.

\subsection{Location of plot establishment}

Twelve observation plots were located in logged-over forest managed using SCLP silvicultural system and the Germplasm Preservation Area (GPCA), at the production forest of the forest concession area Sarpatim Ltd, Central Kalimantan, Indonesia. The objects of the study were GPA representing primary forest, LoA of 9 years after logging, LoA of 7 years after logging, LoA of 5 years after logging, LoA of 3 years after logging and LoA of 1 year after logging. The size of each plot was $100 \mathrm{~m} \times 100 \mathrm{~m}$ for vegetation analysis, as presented at Figure 1.

\subsection{Vegetation analysis}

Methods for data collection used the modified of transects line and plot. Tree level measurement was done by the method of lines, while for regeneration was done 
by the terraced-line method (Goldsmith et al., 1986). The length of the observation plot was $100 \mathrm{~m}$ with a width of $17 \mathrm{~m}$. Each track is divided into five plots measuring $17 \mathrm{~m} \times 20 \mathrm{~m}$. Five plots each divided into four subplots of observation sized $2 \mathrm{~m} \times 2 \mathrm{~m}$ for seedlings observation, $5 \mathrm{~m} \times 5 \mathrm{~m}$ for saplings observation, $10 \mathrm{~m} \times 10 \mathrm{~m}$ for pole level observation, and $17 \mathrm{~m} \times 20 \mathrm{~m}$ for tree observation. The tree level measurement is presented at Figure 2. Data for vegetation analysis were the species and its number at all levels of growth (seedlings, saplings, poles and trees), as well as the diameter and height of the tree trunk on the pole and tree level.

\subsection{Grouping data}

Grouping data according to the FSG groups were pioneer and climax species. The grouping is based on the assumption that the patterns of stand structure dynamics are different for each species group of FSG. Criteria are presented at Table 1.

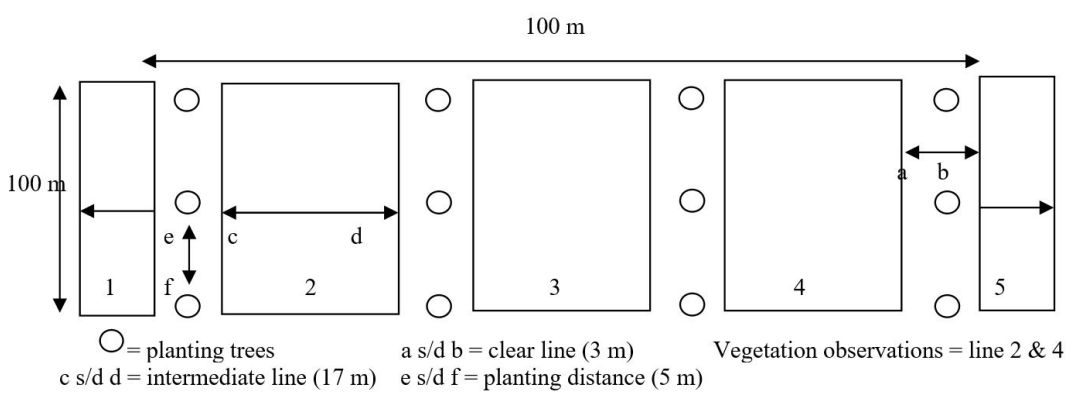

Figure 1. Observation plots layout.

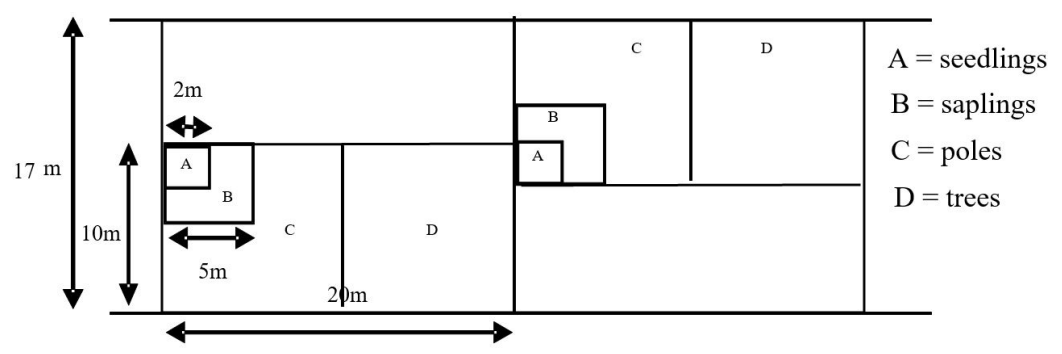

Figure 2. Line design of vegetation analysis.

Table 1. Functional Species Group (FSG) based on the different autecological characteristics.

\begin{tabular}{lll}
\multicolumn{1}{c}{ Characteristic } & \multicolumn{1}{c}{ Pioneer } \\
Synonyms & Light-demander, & Climax \\
& Shade-intolerant & Shade-tolerant \\
Presence & Early secondary forest & Primary forest \\
Site plasticity & High & Low \\
Seeds & Small, produced in high numbers & Large, produced in low numbers not \\
& annually & annually \\
Dispersal of seeds & Very wide & Narrow \\
Viability of seeds & Long & Short \\
Dormancy of seeds & Very often, orthodox & Seldom, recalcitrant \\
Germination of seeds & In full light, open area & In shade, below canopy \\
Growth behavior & Fast growing during the immature & Slow growing during the immature \\
& phase, & phase, \\
Final tree height & Early culmination of the current an- & Late culmination of the current an- \\
nood density & nual increment & nual increment \\
Development & $<20 \mathrm{~m}$ & $>30 \mathrm{~m}$ \\
\hline
\end{tabular}

Source: Pohris (2009). 


\subsection{Data analysis}

\subsubsection{Stand structure}

Stand structure describes the distribution of tree species number (N/ha) based on the tree diameter in the forest area (Husch, 1963).

\subsubsection{Composition of species regeneration}

The availability of sufficient new natural regeneration stands ensures the occurrence of natural forest regeneration. Wyatt-Smith (Wyatt-Smith, 1963) stated that the regeneration is considered adequate if the number of seedlings consists of 1000 stems/ha, saplings of 240 stems/ha, and poles of $75 \mathrm{stems} / \mathrm{ha}$.

\subsubsection{Importance Value Index (IVI)}

Importance Value Index (IVI) is used to analyze dominance (mastery) of a species in a particular community. The mathematical calculation formula of IVI according to Misra (1980) is as follows (Equations 1-6):

$\operatorname{Density~}(\mathrm{K})=\frac{\text { "number of individuals" }(\mathrm{N})}{\text { unit area (ha) }}$

$$
\text { Relative density }(\mathrm{KR})=\frac{\begin{array}{l}
\text { Number of individuals } \\
\text { of one species }(\mathrm{N} / \mathrm{ha})
\end{array}}{\begin{array}{c}
\text { the total number of individuals } \\
\text { of all species }(\mathrm{N} / \mathrm{ha})
\end{array}} \times 100 \%
$$

Frequency $(\mathrm{F})=\frac{\text { inventory points occupied by a given species }}{\text { measure of species distribution across the site }}$

$$
\text { Relative frequency }(\mathrm{FR})=\frac{\begin{array}{l}
\text { Number of individuals of one } \\
\text { speciesfrekuensi suatu jenis }
\end{array}}{\text { frekuensi seluruh jenis }} \times 100 \%
$$

Dominance $(D)=\frac{\text { dominance each species within the study area } \mathrm{m}^{2}}{\text { total basal area per unit area }(\text { ha })}$

$$
\text { Dominansi Relatif }(\mathrm{DR})=\frac{\begin{array}{c}
\text { Number of individuals of } \\
\text { one species }\left(\mathrm{m}^{2} / \mathrm{ha}\right)
\end{array}}{\begin{array}{c}
\text { the total number of individuals } \\
\text { of all species }\left(\mathrm{m}^{2} / \mathrm{ha}\right)
\end{array}} \times 100 \%
$$

\subsubsection{Species Diversity Index ( $\left.H^{\prime}\right)$}

Species diversity index is a parameter used to determine the stability of a community or a community's ability to keep themselves steady from the disruption of its components. Analysis of Diversity Index $\left(\mathrm{H}^{\prime}\right)$ is calculated using the formula diversity of Shanon (Magurran, 1988), as follows (Equation 7):

$$
\mathrm{H}^{\prime}=-\sum_{\mathrm{i}}\left(\frac{\mathrm{ni}}{\mathrm{N}}\right) \ln \left(\frac{\mathrm{ni}}{\mathrm{N}}\right)
$$

$\mathrm{H}^{\prime}=$ Shannon Diversity Index type; $\mathrm{ni}=$ the density value of the $\mathrm{i}$-species; $\mathrm{N}=$ total density.

The criteria for the analysis of species diversity index is: if $\mathrm{H}^{\prime}<2$ the value of the species diversity is in the low category; if $2<\mathrm{H}^{\prime}<3$ the value is in the medium category; finally when $\mathrm{H}^{\prime}>3$ it is in the high category (Magurran, 1988).

\subsection{General condition of the study area}

The study was conducted in the Kalek River and River Nahiang forest group $\left(111^{\circ} 55^{\prime}-112^{\circ} 19^{\prime} \mathrm{E}\right.$ and $1^{\circ} 12^{\prime}-1^{\circ} 56^{\prime} S$ ), district of Seruyan, Katingan, Kotawaringin East, Central Kalimantan Province, Indonesia.

The elevation of the study area ranges from 18-944 m above sea level. The study area is characterized by hilly and undulating terrain. The study sites is dominated by Dystropepts covering area of approximately $61 \%$, and Tropodults covering areas of $39 \%$. Climate types are based Schmidt \& Ferguson. The mean annual rainfall for 145 days per year averaged $3086 \mathrm{~mm}$. The highest rainfall occurs from October to January and the lowest rainfall occurs in July to September. Average humidity ranged between $38.3 \%$ and $85.6 \%$. In terms of hydrology, PT Sarpatim is unique with stream flows of three Watershed as follows: Seruyan, Mentubar, and Mentaya watersheds, respectively.

\section{RESULTS AND DISCUSSION}

\subsection{Species composition}

Analysis of the stand density and species contribution describe a species composition of stands, while the diameter class distribution analysis illustrates the structure of a stand. Species composition of stands is grouped in Functional Group Species into pioneer and climax groups. In addition, by knowing the species composition it is possible to determine the balance of a forest community. According to the functional species group, there are 59 pioneer species and 100 climax species at the entire observation plots. Figure 3 shows the number of pioneer and climax species group, respectively at all growth stages. The community of 
seedlings of pioneer species does not show a considerable difference between plots. If we observe, the number of species at LoA 9 and LoA 5 is lower than in the other plots, respectively 15 and 13 species.

It can be said that the canopy at both plots are quite dense so that the growing site is not suitable for light demanders to grow and occupy the space. In contrast, the recruitment of seedlings of climax species is higher than of pioneer species. In other words, all the residual stands provide growing space favorable for climax species to grow.

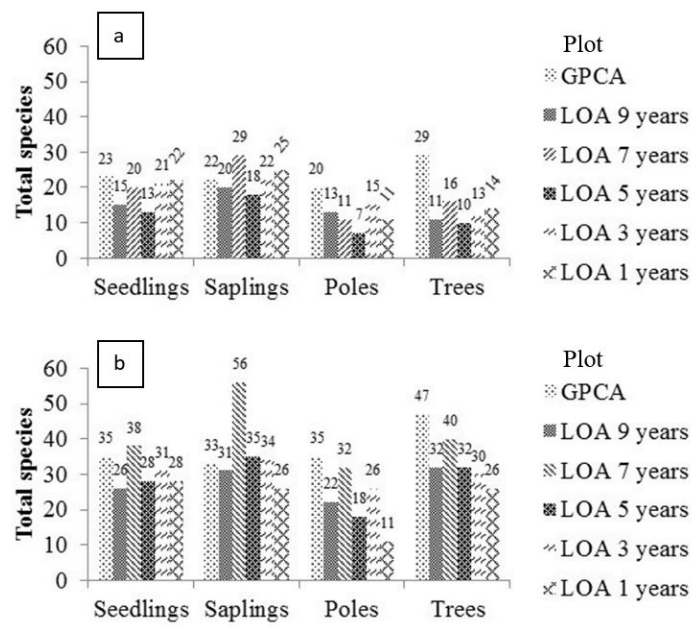

Figure 3. Total species (a) pioneer; (b) climax in all plot observations.
At saplings stage, the species of climax still dominate the entire plots. The high sapling abundance is triggered by higher sun intensity that was still penetrating an open canopy due to selective logging practices (Clark \& Covey, 2012). Similarly for poles and trees. In general, one can say that selective cutting has created growing space, providing stimulus for the development of regeneration climax species. The presence of species in the logged-over forest is affected by intensity of logging. So that regeneration cannot take place properly.

Table 2 shows density and the species contribution at tree level. In general, the larger proportion of tree at all plots is still dominated by climax species, more than 50\%, being the highest at LoA 5, 84.35\%. The number of trees of climax species at GPCA plot that represent primary forest is generally higher compared to logged-over area. It should be emphasized that the areas studied were sufficient in pohon inti or potential trees. According to the regulation, the number of potential trees should be minimum 25 trees per ha. This means that the logged stand would have a better chance of having a higher recruitment of pohon inti for the next cutting cycle (in 30 years).

Table 3 represents density and proportion of climax and pioneer species of poles stage in all observation plots. The density and species contribution at the poles stage of climax species is higher compared to the pioneer species in all study plots, except at plot

Table 2. Tree density and its contribution in all observation plots.

\begin{tabular}{|c|c|c|c|c|c|}
\hline \multirow{2}{*}{ Area } & \multicolumn{2}{|c|}{ Density (N/ha) } & \multirow{2}{*}{ Total } & \multicolumn{2}{|c|}{ Species contribution (\%) } \\
\hline & Pioneer & Climax & & Pioneer & Climax \\
\hline GPCA & 148.75 & 182.50 & 331.25 & 44.91 & 55.09 \\
\hline LOA 9 years & 45.00 & 137.50 & 182.50 & 24.66 & 75.34 \\
\hline LOA 7 years & 52.50 & 137.50 & 190.00 & 27.63 & 72.37 \\
\hline LOA 5 years & 28.75 & 155.00 & 183.75 & 15.65 & 84.35 \\
\hline LOA 3 years & 46.25 & 126.25 & 172.50 & 26.81 & 73.19 \\
\hline LOA 1 years & 51.25 & 105.00 & 156.25 & 32.80 & 67.20 \\
\hline
\end{tabular}

Table 3. Density and its contribution to the entire observation plots on the pole stage.

\begin{tabular}{|c|c|c|c|c|c|}
\hline \multirow{2}{*}{ Area } & \multicolumn{2}{|c|}{ Density (N/ha) } & \multirow{2}{*}{ Total } & \multicolumn{2}{|c|}{ Species contribution (\%) } \\
\hline & Pioneer & Climax & & Pioneer & Climax \\
\hline GPCA & 225 & 325 & 550 & 40.91 & 59.09 \\
\hline LOA 9 years & 200 & 200 & 400 & 50.00 & 50.00 \\
\hline LOA 7 years & 140 & 305 & 445 & 31.46 & 68.54 \\
\hline LOA 5 years & 60 & 165 & 225 & 26.67 & 73.33 \\
\hline LOA 3 years & 130 & 275 & 405 & 32.10 & 67.90 \\
\hline LOA 1 years & 95 & 85 & 180 & 52.78 & 47.22 \\
\hline
\end{tabular}


LoA 1 with 85 individuals of climax poles per ha. The development of poles is affected by the opening of the canopy by selective cutting that improves the light condition for tree in the poles stage.

Regarding the pioneer species, the number of poles is low in plot LoA 5 and then increases in plots LoA 1 , LoA 3, LoA 7 and LoA 9. This trend is rather different in climax species. Density and species contribution of seedlings and saplings stage are presented at Tables 4 and 5 .

The recruitment of seedlings and saplings in logged-over stand give some indications of the impact of selective cutting on natural regeneration. This data can be used to decide whether natural regeneration is sufficient for sustainable management or not.

Regarding the recruitment of seedlings, selective cutting has a positive effect on regeneration density. It can be seen at Table 4 that the number of seedlings are high at all plots. The number of seedlings of climax species is higher compared to pioneer species. Looking at the number of seedlings of climax species there are no consistent trends. The number of climax species at LoA 5 is higher in than other plots. From a low number at LoA 1 and LoA 7, seedlings density increases in the following plots: LoA 3, LoA 9, GPCA and LoA 5. Perhaps, due to the canopy closure, seedlings density declined at LoA 1 and LoA 7. Pioneer species does not play a role at logged-over stand. This may correlate with light intensity caused by selective cutting, which creates small gaps with insufficient light for pioneer. Contrary to this, the gap opportunists may get the chance to establish themselves in the logged-over stands.

Considering the recruitment of saplings, selective cutting still gives stimulus to sapling density as seen at LoA 7 and LoA 9. Looking at the number of sapling of climax species, there is a remarkable increase in the number of saplings from plot LoA 1 to LoA 3 . There is a slight increase to LoA 5 and significantly increases to LoA 7 and then a decrease to LoA 9. According to Wyatt-Smith (1963) the seedlings regeneration is considered sufficient if availability of seedlings is 1000 per ha. All plots of this study have more than 1000 seedlings per ha. Table 5 shows the regeneration at the saplings level exceeds 240 saplings per ha.

In general it can be said that the density of climax species at all levels of regeneration is greater compared to the pioneer species. The results showed that the density at the trees level was still dominated by climax species with the proportion reaching $55 \%$ to $84 \%$. For the poles level, the presence of climax species is still dominant, about $47 \%$ to $73 \%$. As for the level of saplings, the existence of climax and pioneer species are still relatively balanced. It is interesting the dominant existence of climax species at the seedlings level, about $56 \%$ to $83 \%$.

Table 4. Density and its contribution to the entire observation plots on the seedlings stage.

\begin{tabular}{|c|c|c|c|c|c|}
\hline \multirow{2}{*}{ Area } & \multicolumn{2}{|c|}{ Density (N/ha) } & \multirow{2}{*}{ Total } & \multicolumn{2}{|c|}{ Species contribution (\%) } \\
\hline & Pioneer & Climax & & Pioneer & Climax \\
\hline GPCA & 17750 & 22875 & 40625 & 43.69 & 56.31 \\
\hline LOA 9 years & 12375 & 22250 & 34625 & 35.74 & 64.26 \\
\hline LOA 7 years & 11875 & 17625 & 29500 & 40.25 & 59.75 \\
\hline LOA 5 years & 4625 & 23125 & 27750 & 16.67 & 83.33 \\
\hline LOA 3 years & 15750 & 20875 & 36625 & 43.00 & 57.00 \\
\hline LOA 1 years & 13750 & 17625 & 31375 & 43.82 & 56.18 \\
\hline
\end{tabular}

Table 5. Density and its contribution to the entire observation plots on saplings stage.

\begin{tabular}{|c|c|c|c|c|c|}
\hline \multirow{2}{*}{ Area } & \multicolumn{2}{|c|}{ Density (N/ha) } & \multirow{2}{*}{ Total } & \multicolumn{2}{|c|}{ Species contribution (\%) } \\
\hline & Pioneer & Climax & & Pioneer & Climax \\
\hline GPCA & 1360 & 1460 & 2820 & 48.23 & 51.77 \\
\hline LOA 9 years & 2940 & 2880 & 5820 & 50.52 & 49.48 \\
\hline LOA 7 years & 2380 & 3160 & 5540 & 42.96 & 57.04 \\
\hline LOA 5 years & 2060 & 2360 & 4420 & 46.61 & 53.39 \\
\hline LOA 3 years & 2720 & 2200 & 4920 & 55.28 & 44.72 \\
\hline LOA 1 years & 1500 & 1520 & 3020 & 49.67 & 50.33 \\
\hline
\end{tabular}


Silvicultural system of selective cutting and line planting system (SCLP) of the logged-over forest has proved to increase the residual trees. As reported by Pamoengkas (2010), the growth of pole has increased the total residual trees in large quantities.

In our study, as result from selective cutting of the overstory, it is expected the creation of numerous canopy openings, increased light availability and changing in the species composition. This finding in line with the research conducted by Griffis et al. (2001) and Angers et al. (2005), who stated that enhancing light availability induces advance regeneration and
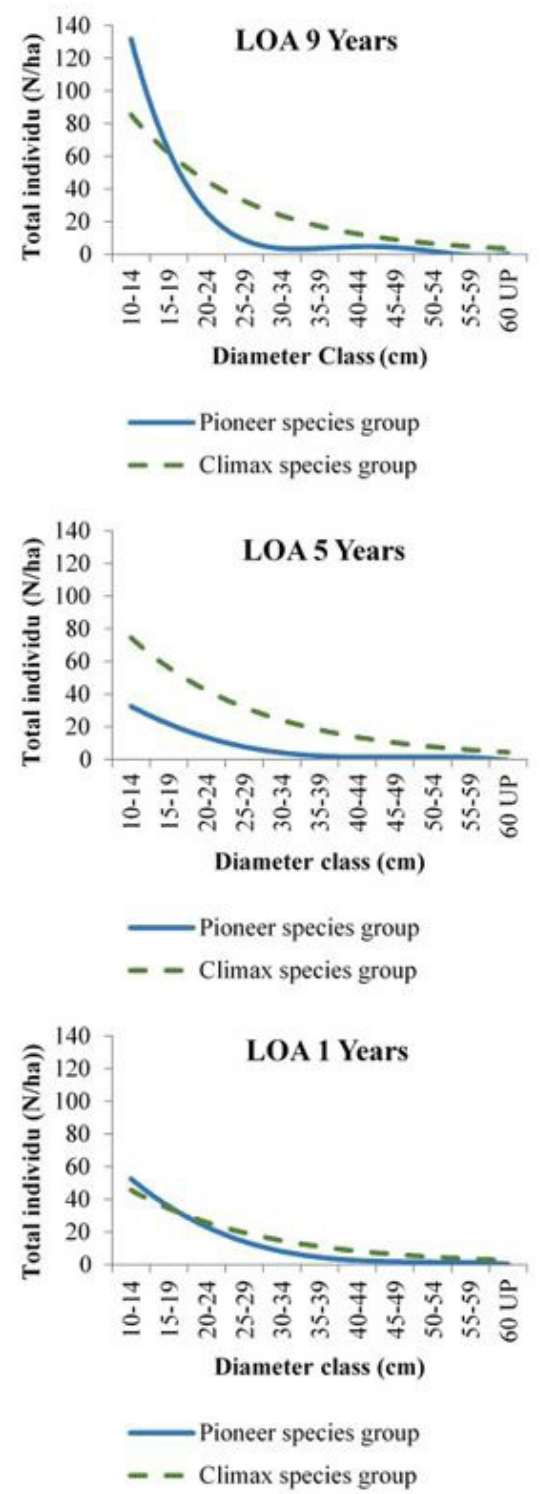

Figure 4. Distribution of stand structure. changes coverage in the understory, even the species richness of understory layer.

\subsection{Stand structure}

Figure 4 shows that the climax species is more dominant compared to the group of pioneer species, except at LoA 9 and LoA 1. It was due to the maintenance activities, i.e. widening of planting line to support plant growth. Widening the distance of planting line results in canopy openness and improves the penetrating light, thus increasing the plants growth rate.
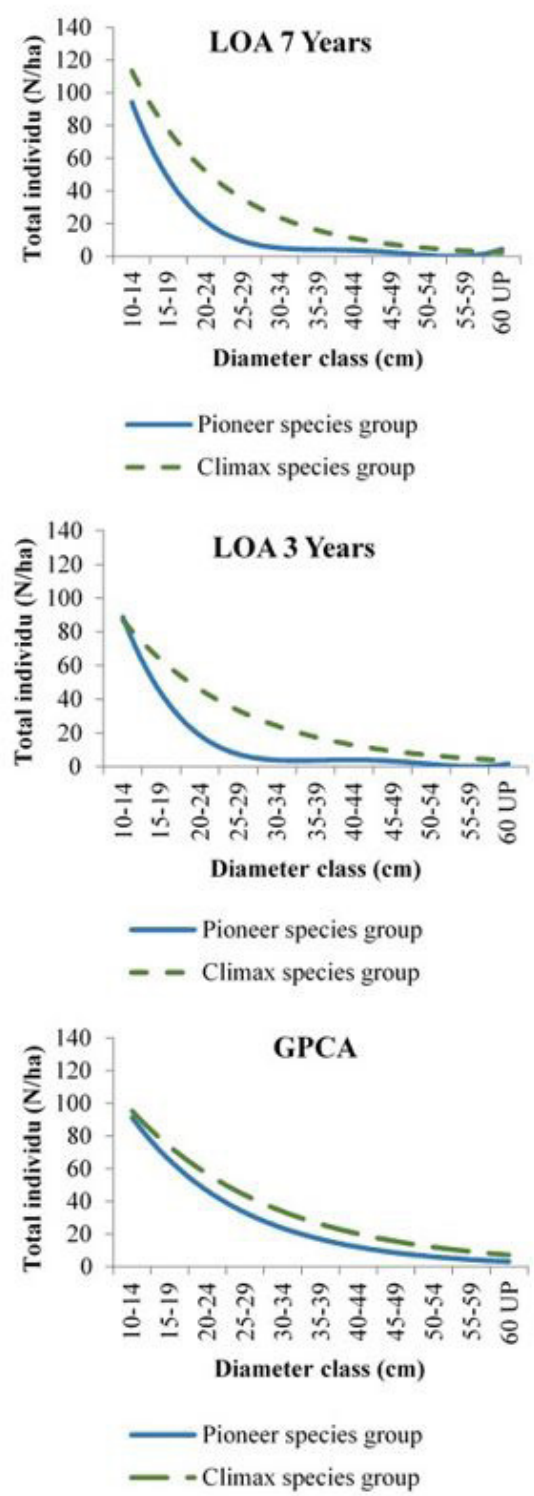
Distribution of stand structure for pioneer and climax species of the entire observations plots tends to follow inverted J curve shape. This result indicates that uneven-aged species composition of the logged-over forests that applied the silvicultural system of selective cutting and line planting system (SCLP) showed a stable condition. The density of smaller diameter trees is relatively high; while the density of larger diameter tree is relatively lower. The condition of the normal forest stand structure of the logged-over forest followed inverted J shape curve corresponds to a balance of residual stand for the next rotation.

\subsection{Index of species diversity}

The index values for species diversity of tree and regeneration at the entire observation plots can be seen at Table 6.

Table 6 shows that the index at all stages have values $>3$. It indicated that species tree diversity and regeneration stands were considered high. This is in accordance with a study carried out at the same location by Utami (2007), who found that the species diversity in that location is quite high. The result of her study showed that the species composition in all stages were very abundant, diverse or heterogeneous. In addition, community species were relatively stable. Community stability refers to the ability of communities to remain unchanged over time. It can be said that the implementation of selective cutting in managing the natural forest in Indonesia still refer to close to nature forestry approach in which the effect of selective cutting on the existing of climax species still can be tolerated.

\subsection{Important Value Index (IVI)}

This index is used to determine the overall importance of each species in the community or the observation plots. The dominant species is the one that utilizes the environment more efficiently than other species in the same community. The dominant species has the highest IVI. A species is considered to play a role if its IVI is $\geq 10 \%$ for seedlings and saplings stage, whereas for poles and trees stage it is $\geq 15 \%$ (Sutisna, 1981).

Table 7 shows that climax species such as those from the group of Dipterocarpaceae dominated at tree

Table 6. Index of species diversity on the observation plots.

\begin{tabular}{|c|c|c|c|c|c|c|}
\hline \multirow{2}{*}{ Strata } & \multicolumn{6}{|c|}{ Index of Diversity (H') } \\
\hline & GPCA & LoA 9 years & LoA 7 years & LoA 5 years & LoA 3 years & LoA 1 years \\
\hline Seedlings & 3.5 & 3.2 & 3.7 & 3.1 & 3.2 & 3.4 \\
\hline Saplings & 3.8 & 3.3 & 4.1 & 3.5 & 3.7 & 3.6 \\
\hline Poles & 3.8 & 3.2 & 3.5 & 3.0 & 3.5 & 3.0 \\
\hline Trees & 4.0 & 3.5 & 3.7 & 3.4 & 3.4 & 3.3 \\
\hline
\end{tabular}

Table 7. Important Value Index above $15 \%$ of the tree level in the observation plots.

\begin{tabular}{|c|c|c|c|c|c|c|c|}
\hline \multirow[b]{2}{*}{ Species } & \multirow[b]{2}{*}{ Group } & \multicolumn{6}{|c|}{ IVI } \\
\hline & & GPCA & $\begin{array}{c}\text { LoA } 9 \\
\text { years }\end{array}$ & $\begin{array}{l}\text { LoA } 7 \\
\text { years }\end{array}$ & $\begin{array}{c}\text { LoA } 5 \\
\text { years }\end{array}$ & $\begin{array}{c}\text { LoA } 3 \\
\text { years }\end{array}$ & $\begin{array}{l}\text { LoA } 1 \\
\text { years }\end{array}$ \\
\hline Castanopsis costata & $\mathrm{C}$ & - & - & $22.3^{\mathrm{a}}$ & $22.8^{\mathrm{b}}$ & - & - \\
\hline Cephalomappa mallotocarpa & $\mathrm{P}$ & - & - & - & - & - & $23.9^{\mathrm{b}}$ \\
\hline Dacryodes rugosa & $\mathrm{P}$ & - & - & - & - & - & 22.7 \\
\hline Dipterocarpus caudiferus. & $\mathrm{C}$ & - & - & - & - & 17.2 & - \\
\hline Hopea dryobalanoides & $\mathrm{C}$ & - & 16.8 & - & - & - & - \\
\hline Koompassia malaccensis & $\mathrm{C}$ & - & - & - & - & - & 15.3 \\
\hline Pternandra caerulescens & $\mathrm{P}$ & - & - & 16.0 & - & - & - \\
\hline Scorodocorpus borneensis & $\mathrm{C}$ & - & - & - & - & - & 19.0 \\
\hline Shorea laevis & $\mathrm{C}$ & - & $36.0^{\mathrm{a}}$ & - & 16.7 & $22.5^{\mathrm{b}}$ & - \\
\hline Shorea parvifolia & $\mathrm{C}$ & $18.4^{\mathrm{a}}$ & - & $18.2^{\mathrm{b}}$ & $34.3^{\mathrm{a}}$ & $40.4^{\mathrm{a}}$ & $43.1^{\mathrm{a}}$ \\
\hline Shorea smithiana & $\mathrm{C}$ & - & $17.4^{\mathrm{b}}$ & - & - & - & - \\
\hline Symplocos cochinchinensis & $\mathrm{P}$ & - & - & - & - & - & - \\
\hline Syzygium borneense & $\mathrm{C}$ & - & - & - & 19.4 & 16.7 & 21.2 \\
\hline
\end{tabular}

$\mathrm{C}=$ Climax; $\mathrm{P}=$ Pioneer; ${ }^{\mathrm{a} D o m i n a n t}$ species; ${ }^{\mathrm{b}} \mathrm{Co}$-dominant species. 
level on the entire observation plots. Dominant species was Shorea parvifolia with the highest Important Value Index in five of the six observation plots. After, Shorea laevis with Index rate dominant in three of the six observation plots. In the Dipterocarpaceae group, the meranti species (Shorea spp) are the most important ones. This group also has a high IVI.

Table 8 shows the important value index at pole stage. It consists of 14 climax and 10 pioneer species. Syzigium borneense showed well distributed at area of five years after cutting (LoA 5, LoA 3 and LoA 1). This species is well adapted at half of all plots. Hopea dryobalanoides, as one of the Dipterocarps group well distributed at half of the total plots. By contrast, the other group of Dipterocarps, such as Shorea parvifolia, Shorea macrophylla, Shorea pauciflora, and Shorea smithiana distributed only at one-sixth of all plots. In general, one can say that climax species at pole stage still dominate the logged-over area, except at the area of one year after cutting (LoA 1), in which the pioneer species are dominant.
The dominant species for seedlings and saplings stage are presented at Tables 9 and 10. As already discussed previously, at pole stage Syzygium borneense showed the highest seedling important value index and occurred in one-third of all plots. Dipterocarps group was found also at young logged-over forest, namely LoA 1, LoA 3 and LoA 5. The three highest IVI level were 26.2\% for Syzigium borneense, 23.2\% for Vatica nitens as representative of climax species, and $21.0 \%$ for Chisocheton sp for pioneer species. In general, each species does not dominate evenly on each observation plots, but they occurred in one to three of all plots.

Table 10 shows that at sapling stages of pioneer species at the logged forest the dominants were Symplocos chocinchinensis (25.6\%) and Macaranga hypoleuca (15.8\%). Antidesma coriaceum of pioneer species were the most dominant group in four of the six observation plots. But there was no dominant sapling stage for GPCA. In general it can be said that, in the seedlings and saplings stage, no species was particularly common at the logged-over area, or it did not show a consistent trend.

Table 8. Important value index above $15 \%$ of poles in the observation plots.

\begin{tabular}{|c|c|c|c|c|c|c|c|}
\hline \multirow{2}{*}{ Species } & & \multicolumn{6}{|c|}{ Important Value Index } \\
\hline & & GPCA & $\begin{array}{c}\text { LoA } 9 \\
\text { years }\end{array}$ & $\begin{array}{l}\text { LoA } 7 \\
\text { years }\end{array}$ & $\begin{array}{l}\text { LoA } 5 \\
\text { years }\end{array}$ & $\begin{array}{l}\text { LoA } 3 \\
\text { years }\end{array}$ & $\begin{array}{l}\text { LoA } 1 \\
\text { years }\end{array}$ \\
\hline Antidesma coriaceum & $\mathrm{P}$ & $15.2^{\mathrm{b}}$ & - & - & - & - & - \\
\hline Aporosa sphaeridophora & $\mathrm{P}$ & - & - & - & - & - & $28.3^{\mathrm{a}}$ \\
\hline Castanopsis costata & $\mathrm{C}$ & - & - & 18.3 & - & - & - \\
\hline Chisocheton $s p$ & $\mathrm{P}$ & - & 16.6 & - & - & - & - \\
\hline Dacryodes rugosa & $\mathrm{P}$ & - & 19.0 & - & - & - & $25.3^{\mathrm{b}}$ \\
\hline Dehaasia caesia & $\mathrm{P}$ & - & - & - & - & - & 24.6 \\
\hline Diospyros rostrate & $\mathrm{C}$ & - & - & - & 18.8 & - & - \\
\hline Hopea dryobalanoides & $\mathrm{C}$ & - & $23.4^{\mathrm{b}}$ & - & 23.8 & - & 16.0 \\
\hline Ilex accuminata & $\mathrm{C}$ & - & - & - & - & 15.3 & - \\
\hline Litsea machilifolia & $\mathrm{C}$ & - & - & - & - & $21.3^{\mathrm{b}}$ & - \\
\hline Macaranga gigantea & $\mathrm{P}$ & - & - & $22.2^{\mathrm{a}}$ & - & - & - \\
\hline Macaranga hypoleuca & $\mathrm{P}$ & - & $40.2^{\mathrm{a}}$ & - & - & - & - \\
\hline Paranephelium xestophyllum & $\mathrm{C}$ & $16.3^{\mathrm{a}}$ & - & - & - & - & - \\
\hline Polyalthia xanthopetala & $\mathrm{P}$ & - & - & - & 15.9 & - & - \\
\hline Pternandra caerulescens & $\mathrm{P}$ & - & - & - & - & - & 16.8 \\
\hline Scorodocorpus borneensis & $\mathrm{C}$ & - & - & - & - & - & 16.6 \\
\hline Shorea macrophylla & $\mathrm{C}$ & - & - & - & 15.4 & - & - \\
\hline Shorea parvifolia & $\mathrm{C}$ & - & - & - & - & - & 20.1 \\
\hline Shorea pauciflora & $\mathrm{C}$ & - & - & 16.5 & - & - & - \\
\hline Shorea smithiana & $\mathrm{C}$ & - & 19.8 & - & - & - & - \\
\hline Strombosia ceylanica & $\mathrm{C}$ & - & - & - & 15.0 & - & - \\
\hline Symplocos cochinchinensis & $\mathrm{P}$ & - & - & - & $30.6^{\mathrm{b}}$ & - & 17.0 \\
\hline Syzygium borneense & $\mathrm{C}$ & - & - & - & $48.6^{\mathrm{a}}$ & $27.9^{\mathrm{a}}$ & 25.1 \\
\hline Syzygium sp & $\mathrm{C}$ & - & - & $21.4^{\mathrm{b})}$ & - & - & - \\
\hline
\end{tabular}

$\mathrm{C}=$ Climax; $\mathrm{P}=$ Pioneer; ${ }^{\mathrm{a} D o m i n a n t}$ species; ${ }^{\mathrm{b}} \mathrm{Co}$-dominant species. 
Table 9. Important value index above $10 \%$ in the regeneration of trees (seedlings) in the observation plot.

\begin{tabular}{|c|c|c|c|c|c|c|c|}
\hline \multirow[b]{2}{*}{ Species } & \multirow[b]{2}{*}{ Group } & \multicolumn{6}{|c|}{ Important Value Index } \\
\hline & & GPCA & $\begin{array}{c}\text { LoA } 9 \\
\text { years }\end{array}$ & $\begin{array}{c}\text { LoA } 7 \\
\text { years }\end{array}$ & $\begin{array}{c}\text { LoA } 5 \\
\text { years }\end{array}$ & $\begin{array}{c}\text { LoA } 3 \\
\text { years }\end{array}$ & $\begin{array}{c}\text { LoA } 1 \\
\text { years }\end{array}$ \\
\hline Antidesma coriaceum & $\mathrm{P}$ & - & 12.7 & - & - & - & - \\
\hline Chisocheton $s p$ & $\mathrm{P}$ & - & $21.0^{\mathrm{a}}$ & - & - & - & - \\
\hline Diospyros rostrata & $\mathrm{C}$ & - & - & - & 13.8 & - & - \\
\hline Gluta wallichii & $\mathrm{C}$ & - & $18.5^{\mathrm{b}}$ & - & - & - & - \\
\hline Hopea dryobalanoides & $\mathrm{C}$ & - & 14.8 & - & - & - & - \\
\hline Coompassia malaccensis & $\mathrm{C}$ & - & - & - & 10.0 & - & - \\
\hline Madhuca erythrophylla & $\mathrm{C}$ & - & - & - & - & - & 13.0 \\
\hline Memecylon edule & $\mathrm{P}$ & - & - & - & - & - & $13.6^{\mathrm{b}}$ \\
\hline Pternandra caerulescens & $\mathrm{P}$ & - & - & $11.7^{\mathrm{b}}$ & - & $16.2^{\mathrm{b}}$ & - \\
\hline Shorea acuminatissima & $\mathrm{C}$ & $20.1^{\mathrm{a}}$ & - & - & - & - & - \\
\hline Shorea laevis & $\mathrm{C}$ & - & 14.2 & - & - & - & - \\
\hline Shorea parvifolia & $\mathrm{C}$ & $10.5^{\mathrm{b}}$ & - & - & - & 10.5 & $20.4^{\mathrm{a}}$ \\
\hline Shorea pauciflora & $\mathrm{C}$ & - & - & - & $17.8^{\mathrm{b}}$ & - & - \\
\hline Shorea smithiana & $\mathrm{C}$ & - & - & - & - & 11.5 & - \\
\hline Syzygium borneense & $\mathrm{C}$ & - & - & - & 13.7 & $26.2^{\mathrm{a}}$ & - \\
\hline Trigonostemon sp & $\mathrm{P}$ & - & - & $14.8^{\mathrm{a}}$ & - & - & - \\
\hline Vatica nitens & $\mathrm{C}$ & - & - & - & $23.2^{\mathrm{a}}$ & - & - \\
\hline
\end{tabular}

$\mathrm{C}=$ Climax; $\mathrm{P}=$ Pioneer; ${ }^{\mathrm{a} D o m i n a n t}$ species; ${ }^{\mathrm{b}} \mathrm{Co}$-dominant species.

Table 10. Important value index above $10 \%$ in the regeneration of trees (saplings) in the observation plots.

\begin{tabular}{lccccccc}
\multicolumn{1}{c}{ Species } & & \multicolumn{7}{c}{ Important Value Index } \\
\cline { 3 - 8 } & Group & GPCA & $\begin{array}{c}\text { LoA 9 } \\
\text { years }\end{array}$ & $\begin{array}{c}\text { LoA 7 } \\
\text { years }\end{array}$ & $\begin{array}{c}\text { LoA 5 } \\
\text { years }\end{array}$ & $\begin{array}{c}\text { LoA 3 } \\
\text { years }\end{array}$ & $\begin{array}{c}\text { LoA 1 } \\
\text { year }\end{array}$ \\
\hline Antidesma coriaceum & $\mathrm{P}$ & - & 12.3 & 10.4 & 12.0 & - & 11.2 \\
Gluta wallichii & $\mathrm{C}$ & - & $13.3^{\mathrm{b}}$ & - & - & - & - \\
Hydnocarpus kunstleri & $\mathrm{C}$ & - & - & $11.7^{\mathrm{a}}$ & - & - & - \\
Macaranga hypoleuca & $\mathrm{P}$ & - & - & - & $15.8^{\mathrm{a}}$ & - & - \\
Madhuca erythrophylla & $\mathrm{C}$ & - & - & - & - & - & $11.9^{\mathrm{b}}$ \\
Paracroton pendulus & $\mathrm{P}$ & - & - & - & - & $10.1^{\mathrm{a}}$ & - \\
Polyalthia anthopetala & $\mathrm{P}$ & - & - & - & $12.4^{\mathrm{b}}$ & - & - \\
Shorea laevis & $\mathrm{C}$ & - & 13.1 & - & 10.8 & - & - \\
Shorea parvifolia & $\mathrm{C}$ & - & - & - & - & - & $14.5^{\mathrm{a}}$ \\
Symplocos cochinchinensis & $\mathrm{P}$ & - & $25.6^{\mathrm{a}}$ & - & - & - & \\
\hline
\end{tabular}

$\mathrm{C}=$ Climax; $\mathrm{P}=$ Pioneer; ${ }^{\mathrm{a} D o m i n a n t}$ species; ${ }^{\mathrm{b}} \mathrm{Co}-$ dominant species.

\section{CONCLUSIONS}

In general, the proportion of the number of climax species in the entire observation plots is greater compared to the pioneer species. As regards for regeneration of seedlings, saplings, and poles, climax species is dominant compared to pioneer species. From the viewpoint of diameter class distribution of climax species and pioneer species, the logged over forests have characteristic of balanced un-even aged forests. Individual selective cutting with diameter limit have not significantly affected the climax species.

\section{ACKNOWLEDGEMENTS}

This study was supported by Forest Concession Right PT. Sarpatim, Central Kalimantan, Indonesia. They provided the forest areas and labor support to conduct the research. The authors would like to express their sincere thank for the support.

\section{SUBMISSION STATUS}

Received: 25 oct., 2017

Accepted: 11 july, 2018 


\section{CORRESPONDENCE TO}

\section{Prijanto Pamoengkas}

Department of Silviculture, Faculty of Forestry, Bogor Agricultural University - IPB, Campus IPB, Km, P.O Box 168, 16680, Darmaga, Bogor, Indonesia

e-mail: prijantop@yahoo.com; ppam@apps.ipb.ac.id

\section{FINANCIAL SUPPORT}

This study was funded by Forest Concession PT. SARPATIM at Central Kalimantan, INDONESIA.

\section{REFERENCES}

Angers VA, Messier C, Beaudet M, Leduc A. Comparison composition and structure in old growth and harvested (selection and diameter limit cuts) northern hardwood stands in Quebec. Forest Ecology and Management 2005; 217(2-3): 275-293. http://dx.doi.org/10.1016/j. foreco.2005.06.008.

Cannon CH, Peart DR, Leighton M, Kartawinata K. The structure of lowland rainforest after selective logging in West Kalimantan, Indonesia. Forest Ecology and Management 1994; 67(1-3): 49-68. http://dx.doi.org/10.1016/03781127(94)90007-8.

Clark JA, Covey KR. Tree species richness and the logging of natural forest: a meta-analysis. Forest Ecology and Management 2012; 276: 146-153. http://dx.doi. org/10.1016/j.foreco.2012.04.001.

Ewusie JY. Elements of tropical ecology. London: Anchor Brandon; 1980. p. 141-144.

Gitay H, Noble IR. What are functional types and how should we seek them? Plant functional types: their relevance do ecosystem properties and global change. Cambridge: Cambridge University Press; 1997.

Goldsmith FB, Harrison CM, Morton AJ. Description and analysis of vegetation. In: Moore PD, Chapman SB, editors. Methods in plant ecology. Oxford: Blackwell Scientific Publication; 1986. p. 437-443.

Griffis KL, Crawford JA, Wagner MR, Moir WH. Understory response to management treatments in northern Arizona ponderosa pine forests. Forest Ecology and Management 2001; 146(1-3): 239-245. http://dx.doi.org/10.1016/S03781127(00)00461-8.
Hendrison J. Damage-controlled logging in managed tropical rain forest in suriname. Wageningen: Agricultural University; 1990. p. 4-10.

Husch B. Forest mensuration and statistics. New York: The Ronald Press; 1963.

MacKinnon K, Hatta G, Halim H, Mangalik A. The ecology of Kalimantan. Singapore: Periplus Edition; 1996. p. 30-407.

Magurran AE. Measuring biological diversity. United Kingdom: TJ International Padstow Corbwall; 1988.

Misra KC. Manual of plant ecology. 2nd ed. New Delhi: IBH Publishing; 1980.

Nussbaum R, Anderson J, Spencer T. Factors limiting the growth of indigenous tree seedlings planted on degraded rainforest soils in Sabah, Malaysia. Forest Ecology and Management 1995; 74(1-3): 149-159. http://dx.doi. org/10.1016/0378-1127(94)03496-J.

Okuda T, Suzuki M, Adachi N, Quah ES, Hussein NA, Manokaran N. Effect of selective logging on canopy and stand structure and tree species composition in a lowland dipterocarp forest in penincular Malaysia. Forest Ecology and Management 2003; 175(1-3): 297-320. http://dx.doi. org/10.1016/S0378-1127(02)00137-8.

Pamoengkas P. Potentialities of line planting technique in rehabilitation of logged over area referred to species diversity, growth and soil quality. Biodiversitas 2010; 11(1):34-39. http://dx.doi.org/10.13057/biodiv/d110108.

Pohris H. Functional species composition and biodiversity conservation in managed forest. In Proceedings of the GAForN International Symposium; 2009; Dehradun, India. Dresden: Institute of International Forestry and Forest Product, Dresden University; 2009.

Suparna N, Purnomo S. Pengalaman Membangun Hutan Tanaman Meranti di PT. Sari Bumi Kusuma, Kalimantan Tengah. Jakarta: PT. Alas Kusuma; 2004.

Sutisna M. Komposisi jenis pohon hutan bekas tebangan di Batullicin, Kalimantan Selatan: deskripsi dan analisa. Bogor: Balai Penelitian Hutan; 1981.

Utami SD. Analisis komposisi jenis dan struktur tegakan di hutan bekas tebangan dan hutan primer di areal IUPHHK PT. Sarmiento Parakantja Timber, Kalimantan Tengah [thesis]. Bogor: Fakultas Kehutanan, Institut Pertanian Bogor; 2007.

Wyatt-Smith, S.J. Manual of Malayan silviculture of inland forest. Malaysia: Forest Research Institute Malaysia; 1963. (Malayan Forest Records; no. 23). 